\title{
Extraction of Oxalic Acid from Bark of Mangrove
}

\author{
Anyikwa Sylvester Obum \\ Co-Authors: E.C. Osoka, M.O. Anusi, J.C. Obijiaku. \\ Chemical Engineering, \\ Federal University Of Technology ,Owerri,
}

\begin{abstract}
Oxalic acid was extracted from sawdust and mangrove bark. Mangrove bark was dried and crushed into different sizes. It was also determined by soaking in ethanol solution for 48 hours. The tannin-free-bark obtained was soaked in a dilute sulphuric acid solution for 24 hours to precipitate calcium sulphate with the release or formation of oxalic acid which is in a crystalline form. The experiment was repeated under various conditions. It was found at the Rhizophora Harrisoni species yielded more oxalic acid than other Rhizophora mangrove species. Sawdust also yielded oxalic acid. Mangrove bark yielded more oxalic acid than sawdust, rhizophora harrisoni specie of mangrove bark yield more oxalic acid.
\end{abstract}

Key words: Oxalic acid, mangrove bark, sawdust.

\section{INTRODUCTION}

The sustainability of the chemical process industries is dependent on-among several other factors-the availability, accessibility and cost of certain industrial chemicals.

One of these important chemicals is oxalic acid. Oxalic acid is a crystalline toxic organic compound widely used as a purifying agent in pharmaceutical industries, precipitating agent in rare earth metal processing and also serve as a bleaching agent in textile and wood industrials.
Oxalic acid is also used as disinfectants to control bacteria's and germs.

Sawdust and mangrove bark are essential raw materials containing calcium oxalate. The calcium oxalate is rich sources of oxalic acid and can be utilized instead of the other inorganic production methods (Dale, 1918).

MATERIAL: Mangrove bark and sawdust

Methods: The mangrove bark obtained from the swampy forest of southern Nigeria was sun dried and size reduced by the processes of grinding. This was classified into several of dust of undersize, $0.1 \mathrm{~mm}, 0.15 \mathrm{~mm}, 0.3 \mathrm{~mm}$, $0.6 \mathrm{~mm}$ and $1.0 \mathrm{~mm}$ and further dried under the influence of the sun.

Methods: Sawdust, Caustic soda and caustic potash where mixed together, dissolved in water and the solution evaporated until it has a specific boiling point of $1.350^{\circ} \mathrm{C}$. The sawdust which is stirred together formed a thick paste. The paste formed was constantly heated and stirred on the iron plate. The temperature is maintained at $205^{\circ} \mathrm{C}\left(40^{\circ} \mathrm{F}\right)$ for an hour or two. A visible dark color of the mass was obtained from text. This contains 1-4 percent of oxalic acid, and about 0.5 percent of formic acid from test.

\section{RESULT/DATA ANALYSIS}

The tables below shows the result obtained from the experiments carried out.

TABLE 1, Yield versus weight

\begin{tabular}{|l|l|l|l|l|}
\hline Sample & Particle size & Weight(g) & Yield(g) & \%yield \\
\hline A & 1.0 & 10.0 & 1.610 & 16.0 \\
\hline B & 1.0 & 14.5 & 2.221 & 15.17 \\
\hline C & 1.0 & 20.8 & 2.931 & 13.94 \\
\hline D & 1.0 & 25.5 & 3.421 & 13.33 \\
\hline E & 1.0 & 30.1 & 4.221 & 13.95 \\
\hline
\end{tabular}

TABLE 2, yields versus species/sample

\begin{tabular}{|l|l|l|l|l|}
\hline Sample & Particle size(mm) & Weight(g) & Yield(g) & \% yield \\
\hline Rhizophora Harrizoni & 1.0 & 20.2 & 4.502 & 21.63 \\
\hline Rhizophora Racemosa & 1.0 & 20.4 & 2.261 & 10.87 \\
\hline Rhizophora Mangle & 1.0 & 20.6 & 3.763 & 18.08 \\
\hline Laguncularia Racemosa & 1.0 & 20.8 & 1.922 & 9.23 \\
\hline Saw dust & 1.0 & 20.10 & 1.522 & 6.22 \\
\hline
\end{tabular}

TABLE 3, yields versus acid concentration

\begin{tabular}{|l|l|l|l|l|}
\hline Sample & Particle size(mm) & Weight(g) & Yield(g) & \% yield \\
\hline A & 1.0 & 18.01 & 2.5 & 8.61 \\
\hline B & 1.0 & 18.03 & 3.5 & 9.72 \\
\hline C & 1.0 & 18.05 & 7 & 9.17 \\
\hline D & 1.0 & 18.07 & 10 & 8.89 \\
\hline E & 1.0 & 18.09 & 14 & 8.39 \\
\hline
\end{tabular}


TABLE 4, yields versus particle size (RHIZOPHORA HARRISONI)

\begin{tabular}{|l|l|l|l|l|}
\hline Sample & Particle size(mm) & Weight(g) & Yield(g) & \% yield \\
\hline A & 1.0 & 19.5 & 1.553 & 7.95 \\
\hline B & 0.6 & 19.5 & 1.012 & 5.18 \\
\hline C & 0.3 & 19.5 & 0.871 & 4.46 \\
\hline D & 0.15 & 19.5 & 0.432 & 2.21 \\
\hline E & 0.2 & 19.5 & 0.123 & 0.62 \\
\hline
\end{tabular}

TABLE 5, Yields versus particle size (RHIZOPHORA RACEMOSA)

\begin{tabular}{|l|l|l|l|l|}
\hline Sample & Particle size(mm) & Yeight(g) & Yield(g) & \% yield \\
\hline A & 1.0 & 19.5 & 1.322 & 6.77 \\
\hline B & 0.6 & 19.5 & 0.962 & 4.92 \\
\hline C & 0.3 & 19.5 & 0.753 & 3.85 \\
\hline D & 0.15 & 19.5 & 0.311 & 1.59 \\
\hline E & 0.2 & 19.5 & 0.021 & 0.10 \\
\hline
\end{tabular}

TABLE 6, Yields versus particle size (RHIZOPHORA MANGLE)

\begin{tabular}{|l|l|l|l|l|}
\hline Sample & Particle size(mm) & Weight(g) & Yield(g) & \%yield \\
\hline A & 1.0 & 19.5 & 1.211 & 6.21 \\
\hline B & 0.6 & 19.5 & 0.843 & 4.31 \\
\hline C & 0.3 & 19.5 & 0.622 & 3.18 \\
\hline D & 0.15 & 19.5 & 0.231 & 1.18 \\
\hline E & 0.2 & 19.5 & 0.12 & 0.06 \\
\hline
\end{tabular}

TABLE 7, Yields versus time

\begin{tabular}{|l|l|l|l|l|l|}
\hline Sample & Particle size $(\mathbf{m m})$ & Weight $(\mathbf{g})$ & Time $(\mathbf{h r})$ & Yield $(\mathbf{g})$ & \% yield \\
\hline A & 1.0 & 20.0 & 0.5 & 1.571 & 7.85 \\
\hline B & 1.0 & 20.0 & 1.0 & 2.513 & 12.55 \\
\hline C & 1.0 & 20.0 & 1.5 & 3.462 & 17.3 \\
\hline D & 1.0 & 20.0 & 2 & 4.821 & 24.0 \\
\hline E & 1.0 & 20.0 & 2.5 & 3.812 & 19.06 \\
\hline
\end{tabular}

TABLE 8, Yields versus weight (Natural/Artificial Cooling)

\begin{tabular}{|c|c|c|c|c|c|c|}
\hline Sample & $\begin{array}{l}\text { Particle size } \\
(\mathbf{m m})\end{array}$ & Weight(g) & $\begin{array}{l}\text { Natural cooling } \\
\text { (Yield) }\end{array}$ & Yield(g) & $\begin{array}{l}\text { Artificial } \\
\text { Cooling } \\
\text { (Yield) }\end{array}$ & $\begin{array}{l}\text { \%yield } \\
\text { (g) }\end{array}$ \\
\hline $\mathrm{A}$ & 1.0 & 10.0 & 1.6 & 16.01 & 1.35 & 13.5 \\
\hline B & 1.0 & 14.5 & 2.2 & 15.17 & 2.02 & 13.93 \\
\hline $\mathrm{C}$ & 1.0 & 20.8 & 2.9 & 13.94 & 2.70 & 12.95 \\
\hline D & 1.0 & 25.5 & 3.4 & 13.33 & 3.10 & 12.16 \\
\hline $\mathrm{E}$ & 1.0 & 30.1 & 4.2 & 13.95 & 3.90 & 12.96 \\
\hline
\end{tabular}

\section{DISCUSSION OF RESULT}

This research work is on the extraction of oxalic acid from mangrove bark. It reveals the optimum method and condition which oxalic acid can be obtained and affected.

Table 1, it is observed that the weight of the yield of oxalic acid increases with respect to the increase in the weight of sample. This is due to the fact that the more oxalic acid yieldable material is available in the sample (more quantity of cutch) and when the cutch reacts with sulphuric acid more oxalic acid obtained.

In fig 4.2 the extraction is done from four different mangrove species, Rhizophora Harrisoni yield the highest amount of oxalic acid, seconded by Rhizophora Recemosa followed by Rhizophora mangle while the least yielding species was Laguncularia Racemosa. The different yield from different species was due to the fact that the various species react with both ethanol and sulfuric acid at different rates. The species that reacts more to complete removal of tannin but that which do not de-tannin completely will inhibit the reaction with sulphuric acid, and will result to a poor oxalic acid yield.

A close examination of fig 4.6 revealed that more oxalic acid was yielded when the hot sample was cool at room temperature (naturally), than when cooled by a refrigerator (artificial cooling). This is simply because by natural cooling, the calcium sulphate precipitate and the free oxalic crystals gradually and slowly dissociates from themselves. The oxalic acid settles at the bottom while the calcium sulphate comes out as a thick gelatinous floating precipitate. But when refrigerated the natural separation between the two compounds is disturbed and most of the oxalic acid are faced out as precipitate along with the calcium sulphate. Hence more yield of oxalic acid is obtained when the samples are cooled at room temperature.

Fig. 4.4 critically reveals tannin inhibits the extraction of oxalic acid. The sample that were soaked in ethanol for 48 hours yielded more oxalic acid than the one soaked for 24 hours, the ethanol react completely with the sample therefore removing the tannin from the mangrove barks, the more tannin free barks were able to yield more 
oxalic acid crystals. On the other hand, soaking for 24 hours did not yield much because the time was not enough for the removal of tannin hence, tannin inhibits the reaction and reduces the yield of oxalic acid is revealed by fig. 4.5. After heating for 2 hours, further heating resulted to decrease in yield of oxalic acid. The reason for the observations is that via, sulphuric acids react with calcium oxalate to give calcium sulphate and oxalic acid to not dissociate unless aided by heating. The heating acids the separation time of the two compounds and have the optimum heating time is 2 hours, since further heating will result to no further yield of oxalic acid.

More so, the effect of particle size on the yield of the oxalic acid can be seen in fig 4.4. It was observed that the yield decreases as the particle size increases. This is because as the particle increases in size the surface contact between the particle and the acid solution begins to reduce and most of the oxalic acid cannot be extracted.

This project enumerates the advance that has been made in the quest for a better yield of oxalic acid from mangrove barks.

\section{CONCLUSION}

This work has proved that oxalic acid; tannin acid calcium sulphate can be obtained from mangrove bark, especially Rhizophora mangrove species. The different mangrove species produced different yields of oxalic acid and the most yielding species was Rhizophora Harrisoni. Also instead of artificial cooling, natural cooling was best for optimum yield.

Tannin greatly inhibits the extraction of oxalic acid and soaking the bark in ethanol solution for 48 hours brings about the optimum yield. The heating of the sample for two hours was also best for optimum yield.

The 3\% of acid $\left(\mathrm{H}_{2} \mathrm{SO}_{4}\right)$ concentration is best for optimum yield, the decreases or increase in acid concentration will lead to less oxalic acid yield or charring of oxalic acid crystals respectively. Finally, for the crystallization of oxalic acid to occur, care should be taken in filtering out all the calcium sulphate.

\section{RECOMMENDATION}

- The minimum size of mangrove bark used in this research is $0.1 \mathrm{~mm}$ further size reduction may enhance better yield.

- The effect of artificial cooling on the yield of oxalic acid should be considered in further research.

\section{REFERENCES}

[1] Browning, B. Ltd (1983). The Chemistry of wood New York Willey (inter-science), Pp. 220-225.

[2] Nekrasor, B. (1969). "Textbook on General Chemistry Mcwilis Publisher, Moscow”. Pp. 299-232.

[3] Caravati, C. and Michael A. McCuigan. Medical Toxicology. Pp. 2003-2004.

[4] Elselvier's Encyclopedia of Organic chemistry (1946) edited by Edith, E. and Joseph, F. Radt. Pp. 330-338.

[5] Farmer R.H. Chemistry (1967). The utilization of woods. Oxford Pergamum Pp. 160-175.

[6] Gustavoson K.H. (1956). The Chemistry of tannin processes academic press Inc. New York Pp. 13-14.

[7] Hillis W.E. (1962). Ed. Wood Extractives New York Academic Press Pp. 460-467.

[8] Analytical Biochemistry Pp. 146-149 by science Direct. Journal of the America Chemistry society (1966) edited by William, S.N.

[9] Kathiresan, K. (2000). A review of studies on Pichavaram Mangrove, South-East India. Hydrobiology Pp. 185-205.

[10] Oxalic acid (www.jtbaker.com)

[11] Oxalic acid and oxalates (www.cloudnet.com)

[12] Oxalic acid, wood bleach, marble polish, rust stain removal (alsnetbiz.com/ homeimprovement /oxalic acid).

[13] Pinder A.R. Rhy: method in organic chemistry products for oxalic acid (www.alibaba.com)

[14] Wikipedia, the free encyclopedia (en./Wikipedia.org)

[15] Acidum oxalicum-oxalic acid (www.Acidum.org) 